\title{
Ethical Branding in the Modern Retail: A Comparison of Italy and UK Ethical Coffee Branding Strategies
}

\author{
Ornella Papaluca $^{1,2}$, Mauro Sciarelli ${ }^{2} \&$ Mario Tani $^{2}$ \\ ${ }^{1}$ Stazione Zoologica Anton Dohrn - National Institute of Marine Biology, Ecology and Biotechnology, Villa \\ Comunale 1 - 80121 - Naples, Italy \\ ${ }^{2}$ Department of Economics, Management, Institutions, University of Naples Federico II, Naples, Italy \\ Correspondence: Ornella Papaluca, Stazione Zoologica Anton Dohrn - National Institute of Marine Biology, \\ Ecology and Biotechnology, Villa Comunale 1 - 80121 - Naples, Italy. E-mail: ornella.papaluca@unina.it
}

Received: December 20, 2019 Accepted: January 22, 2020 Online Published: January 31, 2020

doi:10.5539/ijms.v12n1p1

URL: https://doi.org/10.5539/ijms.v12n1p1

\begin{abstract}
Modern markets can be seen as complex systems of relationships where stakeholders are able to influence the firms' decision-making processes and their value creation processes. Modern businesses should adopt a broader perspective in order to not focus their actions only on maximize economic performance, but to design them considering even their social and environmental impacts on the system as a whole. Firms have to respond to the stakeholders' expectations as a way to obtain the legitimacy needed to create a beneficial environment that will help them in creating a positive effect out of their system of relations, without violating the social contract tying together all the actors in a given system. It follows that, when companies can effectively communicate to their systems' actors how they are following the principles of sustainability and prove that their actions are socially responsible, they can get several advantages. One of the way companies must accomplish this feat is to ask third parties to certify their actions in order to be able to print on their products one of the various Ethical Labels. Using these labels to mark their products can be a tool to influence the consumer to buy from the firm over the competitors, leveraging on a higher legitimacy.

In this paper, we have studied the evolution of the practice of non-financial disclosure trough ethical labels that 14 coffee brands, both in Italy and in England, as a way to understand how, in different markets they have changed over a 5-year time.
\end{abstract}

Keywords: coffee, ethical branding, modern retailing, social responsibility disclosure, sustainability

\section{Introduction}

Today, firms are seen as social actors in a complex system (Boardman \& Sauser, 2008). These system's actors are linked in a web of relationship, driving enterprises to take into account their activities effects on the system as a whole, not only focusing only on those actors they are in a direct relationship with but factoring in even the effects they will have on the other actors. Moreover, the network structure will limit the freedom of the companies as it will propagate, and amplify, both the positive and the negative perceptions of the various actors in the system (Ekeh, 1974; Harrison \& Wicks, 2013) and the companies will have to follow the social contract (Donaldson \& Dunfee, 2002) they have with all the system's actors. It follows that modern companies cannot focus only on the economic performance but they have to adopt a broader vision, encompassing the social and environmental perspectives (Elkington, 1994; Passet, 1996; Sciarelli, 2012); moreover, they are more and more driven to adopt social responsibility disclosure (SRD) (Chauvey, Giordano-Spring, Cho, \& Patten, 2015) practices to influence their stakeholders and their buying behavior (Auger, Devinney, Louviere, \& Burke, 2008).

Several marketing scholars (Bone \& Corey, 2000; Rokka \& Uusitalo, 2008) have found that modern consumers prefer to consume those products they are sharing values with. The product packaging, its design and its gestalt, is one of the ways companies have to communicate with their customers and to show them the values they are adopting (Wansink, Sonka, \& Hasler, 2004; Silayoi \& Speece, 2007).

In this paper, we report the first results of our study on how firms' non-financial disclosure practices using ethical labels in their products, have changed over the last 5 years. In particular, we have looked into the different approach to ethical labeling by 13 coffee brands, 10 in Italy, and 3 in the UK, both in the 2014 and in 
the 2018, as a way to understand how companies look at the evolution of the market.

\section{Literature Review}

\subsection{Corporate Social Responsibilities, Stakeholder Management and Sustainability}

As highlighted by Freeman in 1984, modern companies live in a complex world requiring them to interact with many different stakeholders not only to get access to the resources they need to carry on their activities (Pfeffer \& Salancik, 1978; Frooman, 1999; Papaluca \& Tani, 2016), but even to get a competitive advantage (Harrison, Bosse, \& Phillips, 2010). Acknowledging the existence and the nature of these ties with the organization's stakeholders (Freeman, 1984, p. 96) is needed to define actions that can reduce the negative effects of stakeholder pressures on the company while maximizing the positive ones (Mohr, Webb, \& Harris, 2001) as responding to these pressures in the right way is one of the keys for the companies to get the legitimacy needed to reap the maximum benefits out of the system of relations they are part of (Zimmerman \& Zeits, 2002).

Chauvey et al. (2015) show that adopting standard social responsibility disclosure practices is one of the way companies can effectively obtain this legitimacy; at the same time Maak (2007) showed that the higher legitimacy is linked to the company ability to create a set of relationship with their interlocutors not only mutually beneficial but even consistent, stable over time.

It follows that companies should go beyond focusing their activities only on the economic performance but they should create value for their stakeholders, taking into account the various social and environmental constraints in order to contribute to society's advancement (Elkington, 1994; Passet, 1996; Sciarelli, 2012; Sciarelli, Tani, Landi, \& Papaluca, 2019). Moreover, the focus on sustainability should not be limited to the organization itself, but it should encompass all its value systems (Markley \& Davis, 2007; Matos \& Hall, 2007).

According to several authors (Hoeffler \& Keller, 2002; Sen \& Bhattacharya, 2004; Barnett, 2007), corporate social responsibility (CSR) benefits are linked to the consistent responsible behavior over time as it creates a set of positive perceptions that, in future, will be able to balance the eventually socially irresponsible activities (Brown \& Dacin, 1997; Godfrey, 2005) with a positive corporate association.

Moreover, several authors (De Pelsmacker, Driesen, \& Rayp, 2005; Lamberti \& Lettieri, 2009) have found that there is a niche of consumers willing to pay a higher price to buy an asset that had been produced in a socially responsible manner; Line, Hawley and Krut (2002) got a similar result for ethical behavior. As a consequence, when companies are able to effectively behave in a responsible way, they are able to implement a differentiation strategy, even if only for some of their product lines (Auger, Burke, Devinney, \& Louviere, 2003; Porter \& Kramer, 2006; Carroll \& Shabana, 2010).

\subsection{Social Responsibility Disclosure via Packaging and Ethical Brands}

Social responsibility disclosure activities, the various practices a company can use to disclose to the market their activities toward a sustainable society. Moreover, in the last 20 years, the social responsibility disclosure practices have been strongly developed (Deegan, 2002; Kolk, 2003).

Social responsibility disclosure can focus on various topics and it is usually difficult to draw general criteria on social responsibility disclosure as it mostly depends on the business area the company operates (Ingram, 1978); but Branco and Rodrigues (2008) show that they usually focus on four issues: environment, human resources, products and consumers, community engagement. On a similar page, Hanss and Böhm (2012) have found that corporations have been driven by stakeholders' requests towards environmental sustainability and other issues related to social sustainability.

Even, Dawkins and Lewis (2003) highlighted that market actors have an interest in getting access to this information, although other authors (Folkes \& Kamins, 1999) point out that the social responsibility disclosure positive effects are coupled with more negative ones when the company adopts an unethical behavior.

Several authors (Nilsson, Tunçer, \& Thidell, 2004; De Pelsmacker \& Janssens, 2007) have shown that insufficient transparency is one of the main social responsibility disclosure limitations, undermining their credibility. This risk is stronger when companies try to use social responsibility disclosure as a tool of brand reputation management (Neu, Warsame, \& Pedwell, 1998; Hooghiemstra, 2000) rather than as a way to help external stakeholders in understanding their social performance (Berthelot, Cormier, \& Magnan, 2003; Dubbink, Graafland, \& Van Liedekerke, 2008).

Even if today, companies have access to multiple media to use in their own social responsibility disclosure activities (Jenkins \& Yakovleva, 2006), product packaging is one of the main tools company have in social responsibility disclosure as it does not only have a logistic and functional use (containment, protection, 
fragmentation, transportation, storage), but also for its role in communication process (Prendergast \& Pitt, 1996). In our modern self-service economy (McDaniel \& Baker, 1977), the role of packaging is becoming more and more crucial, since it is the last things consumers see before making the decision purchase (Ampuero \& Vila, 2006). Pearce (1999) acknowledges that packaging becomes more relevant when the consumer has only a limited knowledge of the products and, companies can use brands, symbols or logos (Azad \& Hamdavipour, 2012) in order to communicate personal and social values (Underwood, 2003). It follows that packaging becomes more relevant in consumer relationships and some companies invest more on the design of the packaging of the product than on its advertising (Dickson, 1994).

Ethical brands, logos that companies can use to signal to stakeholders, mainly consumers, the respect of some basic principles (Font \& Harris, 2004), can be used to prove if the company compliance with a given disciplinary (Teisl, Rubin, \& Noblet, 2008).

Ethical labels, when known, help consumers in identifying more sustainable products, and, therefore, it may influence their purchasing behavior (Galarraga Gallastegui, 2002; Hanss \& Böhm, 2012). Other authors, however, stressed that the use of ethical brands faces also some critical issues, both related to their content and to the ability of consumers to fully understand their meaning. Van Amstel, Driessen and Glasbergen (2008) have criticized these labels as they are voluntary ones and their rules are often not enough rigid; on the same page, Galarraga Gallastegui (2002) points out that a general lack of objective measures. On the other side, the perception of consumers of an ethical label brand is rooted on their limited knowledge of the mark's real meaning (Codron, Siriex, \& Reardon, 2006), and on the risks of information overload when there are too many labels (Thøgersen, 2000).

\section{Method: Multiple Case Study}

\subsection{Research Context}

The literature review highlights that a socially responsible behavior can be used in corporate communication processes to influence its stakeholders and get better reactions to the firm's activities (Brown \& Dacin, 1997; Godfrey, 2005). In particular, the literature review on social responsibility disclosure has highlighted how the packaging (Underwood, 2003) is widely used to convey these informations as a consequence of the Modern Distribution (i.e., GDO, if we use the Italian acronym) self-service approach (McDaniel \& Baker, 1977; Rettie \& Brewer, 2000). Moreover, since the packaging communication process is implemented through trademarks, symbols and logos (Azad \& Hamdavipour, 2012), it is especially suited to show off ethical labels the corporation has been certified with as a way to enable them to show consumers, and other stakeholders, that their commitment to sustainability issues is not a façade, but underlies a set of shared values (Font \& Harris, 2004).

In this paper we present the preliminary results from a single sector in order to reduce the variability (Yin, 2003): ground coffee. We have chosen to focus on ground coffee as it is a commodity that is produced abroad (Catturani, Nocella, Romano, \& Stefani, 2008) and it has been previously studied (De Pelsmacker et al., 2005; Arnot, Boxall, \& Cash, 2006) have shown how, in this specific market, socially responsible business behavior results in a competitive advantage, a factor encouraging companies towards social responsibility disclosure (Mackey, Mackey, \& Barney, 2007).

Moreover, there are several ethical certifications aimed at analyzing the sustainability of production processes and supply chains (Perna, 1998). In addition, as with all food and agricultural products, firms have the opportunity to also adopt organic farming, to further emphasize their responsible behavior towards the natural environment.

In this sector there are only few brands, helping consumers to know them and to understand them more easily (Hanss \& Böhm, 2012), limiting the information overload risk (Thøgersen, 2000). The Table 1 shows the main sustainability certifications used by coffee importers on their packaging. 
Table 1. Most used ethical standards in coffee

\begin{tabular}{|c|c|c|c|c|c|c|c|}
\hline \multirow[b]{2}{*}{ Labels } & \multicolumn{3}{|l|}{ Institution } & \multicolumn{4}{|l|}{ Transparency } \\
\hline & International & Private? & Coop? & Verification & \multicolumn{2}{|l|}{$\begin{array}{l}\text { Independent } \\
\text { certified }\end{array}$} & Traceability \\
\hline Europe Ecolabel & YES & $\mathrm{NO}$ & NO & YES & YES & & YES \\
\hline $\begin{array}{l}\text { Fair-Trade Label } \\
\text { Organization }\end{array}$ & YES & YES & YES & YES & NO & & YES \\
\hline Rain Forest Alliance ${ }^{* * *}$ & YES & YES & NO & YES & NO & & NO \\
\hline \multirow[t]{3}{*}{$U T Z * *$} & YES & YES & NO & YES & YES & & NO \\
\hline & & \multicolumn{6}{|c|}{ Subject } \\
\hline & & Supply Chain & \multicolumn{2}{|c|}{ Firm } & Product & \multicolumn{2}{|c|}{$100 \%$ labeled } \\
\hline \multirow{4}{*}{\multicolumn{2}{|c|}{$\begin{array}{l}\text { Europe Ecolabel } \\
\text { Fair-Trade Label Organization } \\
\text { Rain Forest Alliance } * * * \\
\text { UTZ ** }\end{array}$}} & YES & \multicolumn{2}{|c|}{$\mathrm{NO}$} & YES & \multicolumn{2}{|l|}{$\mathrm{NO}$} \\
\hline & & YES & \multicolumn{2}{|c|}{ NO } & YES & \multicolumn{2}{|l|}{ YES } \\
\hline & & NO & \multicolumn{2}{|c|}{ YES } & NO & \multicolumn{2}{|c|}{ NO } \\
\hline & & YES & \multicolumn{2}{|c|}{ YES } & YES & \multicolumn{2}{|c|}{$\mathrm{NO}$} \\
\hline \multicolumn{8}{|c|}{ Social Performance } \\
\hline & & Child Labour & $\begin{array}{l}\text { Freedom of } \\
\text { union }\end{array}$ & Subcontractors & \multicolumn{2}{|c|}{$\begin{array}{l}\text { Social } \\
\text { Development }\end{array}$} & Land Rights \\
\hline \multirow{4}{*}{\multicolumn{2}{|c|}{$\begin{array}{l}\text { Europe Ecolabel } \\
\text { Fair-Trade Label Organization } \\
\text { Rain Forest Alliance**** } \\
\text { UTZ ** }\end{array}$}} & N/A & $\mathrm{N} / \mathrm{A}$ & $\mathrm{N} / \mathrm{A}$ & $\mathrm{N} / \mathrm{A}$ & & N/A \\
\hline & & YES & YES & YES & YES & & NO \\
\hline & & YES & YES & YES & NO & & YES \\
\hline & & $\mathrm{NO}$ & NO & $\mathrm{NO}$ & NO & & NO \\
\hline & & Environmental pe & ormance & & & & \\
\hline & & $\begin{array}{l}\text { Pesticides and } \\
\text { Fertilizers }\end{array}$ & GMO & $\begin{array}{l}\text { Waste } \\
\text { Management }\end{array}$ & $\begin{array}{l}\text { Rainfol } \\
\text { Usage }\end{array}$ & & Wildlife \\
\hline Europe Ecolabel & & YES & NO & YES & $\mathrm{N} / \mathrm{A}$ & & NO \\
\hline Fair-Trade Label Organizatic & & NO & NO & YES & NO & & NO \\
\hline Rain Forest Alliance $* * *$ & & NO & NO & YES & NO & & YES \\
\hline $\boldsymbol{U T Z} * *$ & & YES & YES & NO & NO & & NO \\
\hline
\end{tabular}

Note. * A company has to follow more than $80 \%$ of the standard criteria to be certified.

** Merged from December 2018, no common standard.

\subsection{Research Design: The Cases Description and the Factors Investigated}

Our analysis has been focused on two geographically distinct markets: the Italian and the English one. We investigated UK-based companies as it is an advanced market as, according to FLO (Note 1) data (2012), Fair-Trade coffee has grown by about 13 times from 2001 to 2010, reaching almost $25 \%$ of the entire national market. The cases we have selected have been shown in the following Table 2. As the table shows we have analyzed 10 Italian brands ( 3 private labels, 3 responsible brands, and 4 traditional ones) and 3 main UK-based brands ( 1 responsible label and 2 private labels). Even if the number of producers is different, as shown in Table 2 the number of different product label in the 2014 was similar (54 in Italy, and 47 in UK). 
Table 2. The cases

\begin{tabular}{|c|c|c|c|c|c|c|c|}
\hline \multirow[b]{2}{*}{ Market } & \multirow[b]{2}{*}{ Company } & \multirow[b]{2}{*}{ Brand } & \multirow[b]{2}{*}{ Abbr. } & \multicolumn{2}{|l|}{2014} & \multicolumn{2}{|l|}{2018} \\
\hline & & & & Products & Certified & Products & Certified \\
\hline \multirow[t]{20}{*}{ Italy } & Alce Nero & Alcenero & $A N$ & 2 & 2 & 3 & 3 \\
\hline & Altromercato & Altromercato & $A M A$ & 5 & 5 & 5 & 5 \\
\hline & & BioCaffè & $A M B$ & 2 & 3 & 4 & 4 \\
\hline & & Monorigine & $A M M$ & 5 & 5 & 3 & 3 \\
\hline & Cafè do Brazil & Kimbo & $K M B$ & 6 & 0 & 10 & 1 \\
\hline & & Kosè & KOSE & 2 & 0 & 2 & 0 \\
\hline & Carrefur & Normal / Classic & $C R F N$ & 5 & 0 & 5 & 0 \\
\hline & & Selection & $C R F S$ & 2 & 2 & 2 & 2 \\
\hline & & Bio & $C R F B$ & - & - & 1 & 1 \\
\hline & CONAD & Conad & $C O N A D$ & 3 & 2 & 7 & 0 \\
\hline & & Conad "Il Biologico" & CONBIO & 1 & 1 & 1 & 1 \\
\hline & Coop & Coop & COOP & 2 & 0 & 5 & 0 \\
\hline & & FiorFiore & COOPF & 1 & 1 & 1 & 0 \\
\hline & & Solidal Coop & COOPS & 2 & 2 & 2 & 2 \\
\hline & Ecor & Ecor & $E C O R$ & 1 & 1 & 2 & 2 \\
\hline & & Natura Si & NATS & 1 & 1 & - & - \\
\hline & Illy Caffè & Illy & $I L L Y$ & 3 & 0 & 7 & 0 \\
\hline & Lavazza & Lavazza & $L V Z Z$ & 7 & 0 & 7 & 0 \\
\hline & & !Tierra! & $! T !$ & - & - & 5 & 5 \\
\hline & Passalacqua & Passalacqua & PSSL & 4 & 0 & 4 & 0 \\
\hline \multirow[t]{7}{*}{ UK } & Cafedirect & Monorigine & $\mathrm{CDM}$ & 4 & 4 & 5 & 5 \\
\hline & & Organic & $\mathrm{CDO}$ & - & - & 4 & 4 \\
\hline & & Blends & $\mathrm{CDB}$ & 6 & 6 & 5 & 5 \\
\hline & Sainsbury & Fair-Trade & SBFT & 11 & 11 & 7 & 7 \\
\hline & & Taste the difference & SBTTF & 10 & 10 & 9 & 9 \\
\hline & Tesco & Local & TSCLC & 6 & 6 & 6 & 1 \\
\hline & & Finest & TSCFIN & 10 & 9 & 7 & 7 \\
\hline
\end{tabular}

For each of these products, we have looked if they were used as a media for social responsibility disclosure, and - as the various certification are really different - we have looked into which one they used. The factors are been studied have been reported in Table 3 .

Table 3. The factors investigated

\begin{tabular}{llll}
\hline Indicator & Description & Values & \\
\hline EP & Organic Product or RFA Certified (Note 2) & NO & YES \\
SP & FLO or UTZ Certified (Note 3) & NO & YES \\
Country of Origin & Explicit definition of the Coffee Beans & NO & YES \\
Blend of Taste & \% of Arabica Coffee Beans or a Description of Taste & NO & YES \\
\hline
\end{tabular}

We have not looked in the companies Social Report as many of them (mostly the Modern Distributors) even if they have a social report do not disclose their activities at the product level so the data would have been dishomogeneous with those of the packaging.

\section{Discussion of Results}

In the Tables 4 and 5, there were reported the main findings in the two years. 
Table 4. Results in the 2014

\begin{tabular}{|c|c|c|c|c|c|c|c|c|}
\hline \multirow[b]{2}{*}{ Market } & \multirow[b]{2}{*}{ Company } & \multirow[b]{2}{*}{ Brand } & \multirow[b]{2}{*}{ Abbr. } & \multicolumn{5}{|l|}{2014} \\
\hline & & & & Products & $\mathbf{E P}$ & SP & $\mathrm{CoO}$ & Blend of Taste \\
\hline \multirow[t]{21}{*}{ Italy } & Alce Nero & Alcenero & $A N$ & 2 & 2 & 2 & 2 & 2 \\
\hline & Altromercato & Altromercato & $A M A$ & 5 & 0 & 5 & 0 & 5 \\
\hline & & BioCaffè & $A M B$ & 2 & 2 & 2 & 0 & 2 \\
\hline & & Monorigine & $A M M$ & 5 & 5 & 5 & 5 & 5 \\
\hline & Cafè do Brazil & Kimbo & $K M B$ & 6 & 0 & 0 & 0 & 6 \\
\hline & & Kosè & KOSE' & 2 & 0 & 0 & 0 & 2 \\
\hline & Carrefur & Normal / Classic & $C R F N$ & 5 & 0 & 0 & 0 & 5 \\
\hline & & Selection & CRFS & 2 & 0 & 0 & 2 & 2 \\
\hline & & Bio & $C R F B$ & - & - & - & - & - \\
\hline & CONAD & Conad & $C O N A D$ & 3 & 0 & 0 & 0 & 2 \\
\hline & & Conad "Il & CONBIO & 1 & 1 & 1 & 0 & 1 \\
\hline & & Biologico" & & & & & & \\
\hline & Coop & Coop & СOOP & 2 & 0 & 0 & 0 & 0 \\
\hline & & FiorFiore & $C O O P F$ & 1 & 0 & 0 & 1 & 1 \\
\hline & & Solidal Coop & COOPS & 2 & 2 & 2 & 1 & 2 \\
\hline & Ecor & Ecor & $E C O R$ & 1 & 1 & 1 & 0 & 1 \\
\hline & & Natura Si & NATS & 1 & 1 & 1 & 0 & 1 \\
\hline & Illy Caffè & Illy & $I L L Y$ & 3 & 0 & 0 & 0 & 3 \\
\hline & Lavazza & Lavazza & $L V Z Z$ & 7 & 0 & 0 & 0 & 7 \\
\hline & & !Tierra! & $! T !$ & - & - & - & - & - \\
\hline & Passalacqua & Passalacqua & $P S S L$ & 4 & 0 & 0 & 0 & 3 \\
\hline \multirow[t]{7}{*}{$\mathbf{U K}$} & Cafedirect & Monorigine & $\mathrm{CDM}$ & 4 & 0 & 4 & 4 & 4 \\
\hline & & Organic & $\mathrm{CDO}$ & - & - & - & - & - \\
\hline & & Blends & $\mathrm{CDB}$ & 6 & 0 & 6 & 0 & 6 \\
\hline & Sainsbury & Fair-Trade & SBFT & 11 & 1 & 11 & 1 & 11 \\
\hline & & Taste the difference & SBTTF & 10 & 0 & 10 & 9 & 10 \\
\hline & Tesco & Local & TSCLC & 6 & 6 & 0 & 1 & 6 \\
\hline & & Finest & TSCFIN & 10 & 1 & 9 & 9 & 10 \\
\hline
\end{tabular}

The results have been displayed graphically in the Figure 1 where there are the percentage of products disclosing the environmental and the social activities by brands.

The picture highlights the presence of four main cluster: Traditional Producers; Partially Responsible Producers; Fair-Trade Producers; Ethical Producers.

The first cluster is composed by the Italian traditional producers that do not do any kind of social disclosure through the packaging, while focusing their communication on their brand. The second cluster is composed by the Italian Coop and by Tesco in UK. These big players have created specific lines to disclose their socially responsible activities oversea.

The third cluster is composed by the Fair-Trade producers mostly focused on Social Peroformance and with a limited focus on the Environmental one.

In the last cluster (Ecor and Alce Nero in Italy), there are the two producers that are fully leveraging their CSR related activities. AltroMercato, in Italy, is in the middle ground between these last two clusters. 


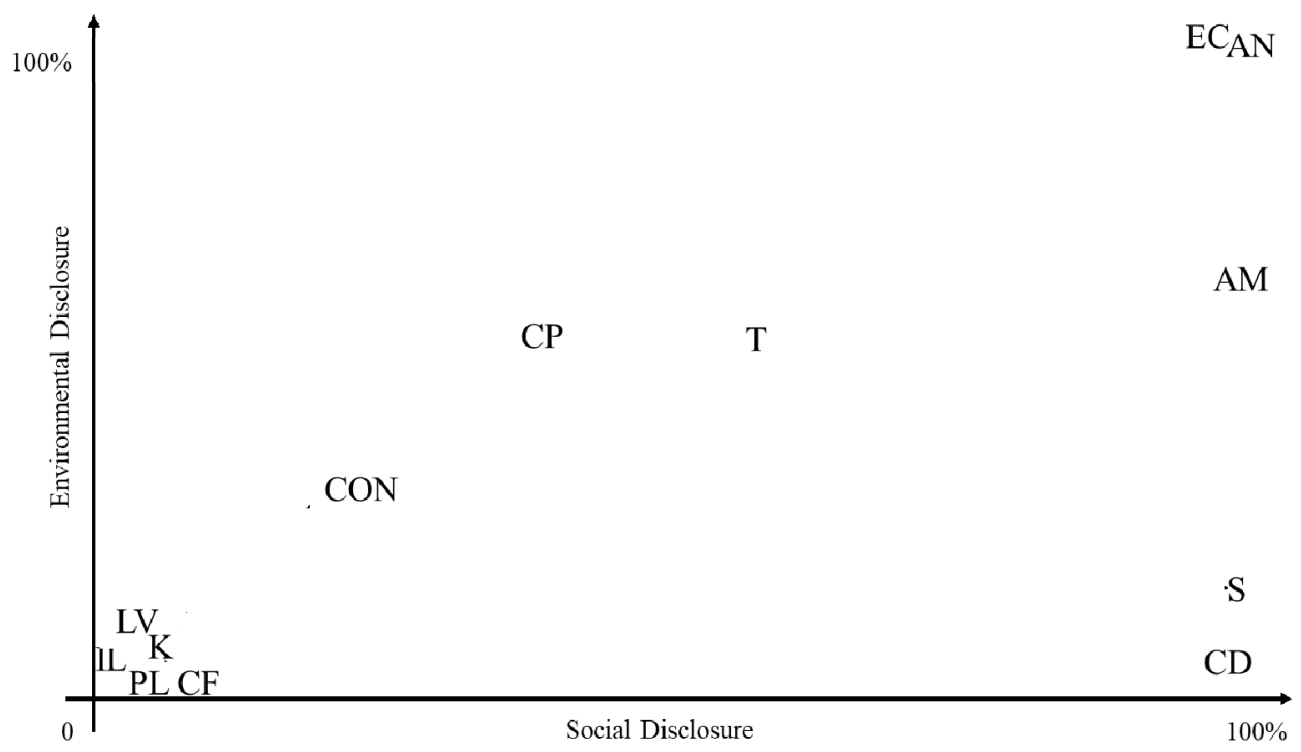

Figure 1. SRD by coffee Brands in the 2014

Note. $\mathrm{AN}=\mathrm{Alce}$ Nero, $\mathrm{AM}=\mathrm{Altromercato}, \mathrm{K}=\mathrm{Cafè}$ do Brazil, $\mathrm{CF}=$ Carrefur, $\mathrm{CON}=\mathrm{CONAD}, \mathrm{CP}=\mathrm{Coop}, \mathrm{EC}=\mathrm{Ecor}, \mathrm{IL}=\mathrm{Illy} \mathrm{Caffè,}, \mathrm{LV}=\mathrm{Lavazza}$, $\mathrm{PL}=$ Passalacqua, $\mathrm{CD}=$ Cafedirect, $\mathrm{S}=$ Sainsbury, $\mathrm{T}=$ Tesco.

The results in the 2018 investigation have been reported in Table 5.

Table 5. Results in the 2018

\begin{tabular}{|c|c|c|c|c|c|c|c|c|}
\hline \multirow[b]{2}{*}{ Market } & \multirow[b]{2}{*}{ Company } & \multirow[b]{2}{*}{ Brand } & \multirow[b]{2}{*}{ Abbr. } & \multicolumn{5}{|l|}{2018} \\
\hline & & & & Products & EP & SP & $\mathrm{CoO}$ & Blend of Taste \\
\hline \multirow[t]{20}{*}{ Italy } & Alce Nero & Alcenero & $A N$ & 3 & 3 & 3 & 3 & 3 \\
\hline & Altromercato & Altromercato & $A M A$ & 5 & 0 & 5 & 0 & 5 \\
\hline & & BioCaffè & $A M B$ & 4 & 4 & 4 & 0 & 4 \\
\hline & & Monorigine & $A M M$ & 3 & 3 & 3 & 3 & 3 \\
\hline & Cafè do Brazil & Kimbo & $K M B$ & 10 & 1 & 1 & 0 & 10 \\
\hline & & Kosè & KOSE, & 2 & 0 & 0 & 0 & 2 \\
\hline & Carrefur & Normal / Classic & $C R F N$ & 5 & 0 & 0 & 0 & 5 \\
\hline & & Selection & CRFS & 2 & 0 & 0 & 2 & 2 \\
\hline & & Bio & $C R F B$ & 1 & 1 & 1 & 1 & 0 \\
\hline & CONAD & Conad & $C O N A D$ & 7 & 0 & 0 & 0 & 7 \\
\hline & & $\begin{array}{l}\text { Conad "Il } \\
\text { Biologico" }\end{array}$ & CONBIO & 1 & 1 & 1 & 1 & 1 \\
\hline & Coop & Coop & COOP & 5 & 0 & 0 & 0 & 5 \\
\hline & & FiorFiore & COOPF & 1 & 0 & 0 & 1 & 1 \\
\hline & & Solidal Coop & COOPS & 2 & 2 & 2 & 1 & 0 \\
\hline & Ecor & Ecor & $E C O R$ & 2 & 2 & 2 & 0 & 0 \\
\hline & & Natura Si & NATS & - & - & - & - & - \\
\hline & Illy Caffè & Illy & $I L L Y$ & 7 & 0 & 0 & 4 & 7 \\
\hline & Lavazza & Lavazza & LVZZ & 7 & 0 & 0 & 0 & 7 \\
\hline & & !Tierra! & $! T !$ & 5 & 5 & 5 & 5 & 5 \\
\hline & Passalacqua & Passalacqua & PSSL & 4 & 0 & 0 & 0 & 4 \\
\hline \multirow[t]{7}{*}{ UK } & Cafedirect & Monorigine & $\mathrm{CDM}$ & 5 & 1 & 5 & 5 & 5 \\
\hline & & Organic & $\mathrm{CDO}$ & 4 & 4 & 2 & 2 & 4 \\
\hline & & Blends & $\mathrm{CDB}$ & 5 & 1 & 5 & 5 & 7 \\
\hline & Sainsbury & Fair-Trade & SBFT & 7 & 1 & 7 & 1 & 7 \\
\hline & & Taste the difference & SBTTF & 9 & 0 & 9 & 9 & 9 \\
\hline & Tesco & Local & TSCLC & 6 & 6 & 0 & 1 & 6 \\
\hline & & Finest & TSCFIN & 7 & 0 & 7 & 7 & 7 \\
\hline
\end{tabular}


As before, the social responsibility disclosure brands are been represented in Figure 2.

After 5 years, the cluster of the traditional players has reacted to the market need of social responsibility disclosure and Cafè do Brasil, with the Italian Private label have created a different cluster with around the $20 \%$ of certified product lines.

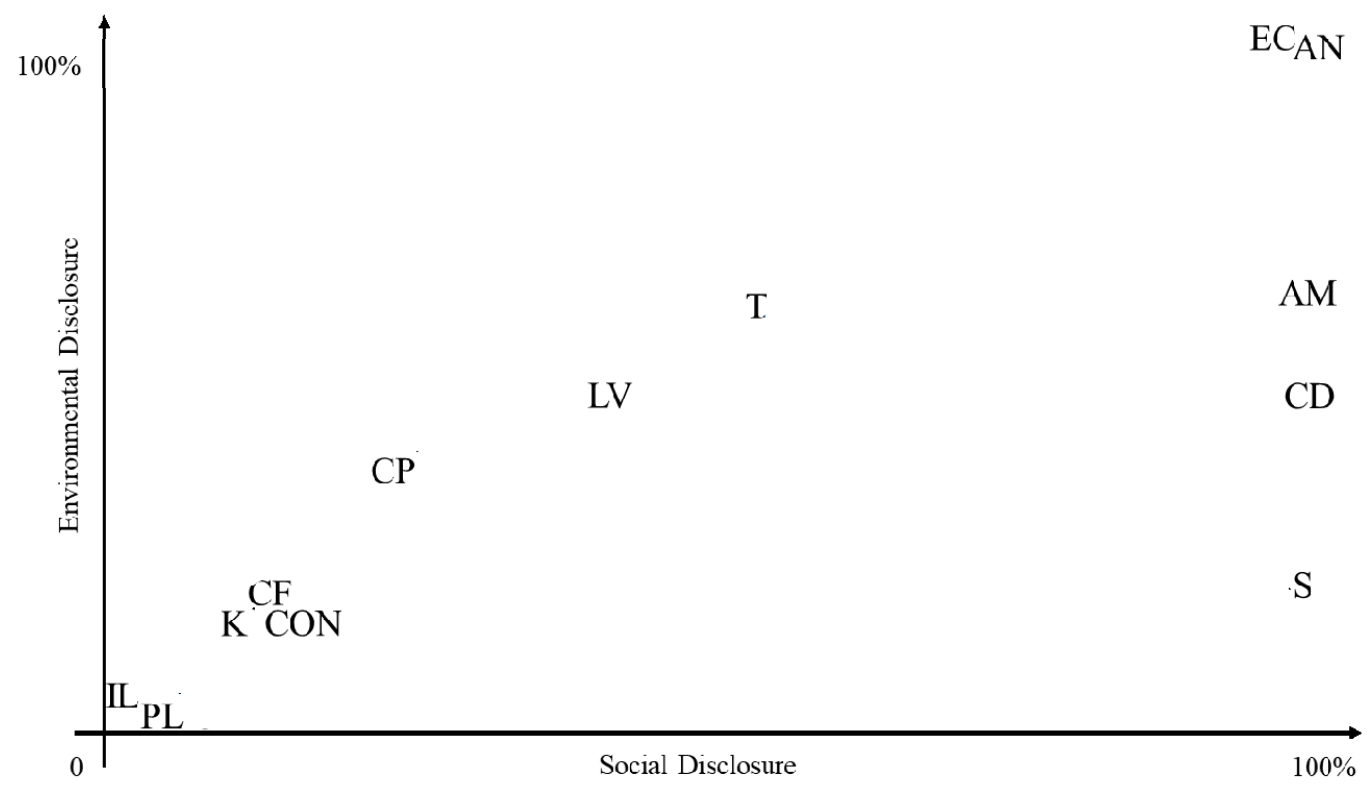

Figure 2. SRD by coffee brands in the 2018

Note. $\mathrm{AN}=\mathrm{Alce}$ Nero, $\mathrm{AM}=$ Altromercato, $\mathrm{K}=\mathrm{Cafè}$ do Brazil, $\mathrm{CF}=$ Carrefur, $\mathrm{CON}=\mathrm{CONAD}, \mathrm{CP}=\mathrm{Coop}, \mathrm{EC}=\mathrm{E}$ cor, $\mathrm{IL}=\mathrm{Illy} \mathrm{Caffè,} \mathrm{LV}=\mathrm{Lavazza}$, $\mathrm{PL}=$ Passalacqua, $\mathrm{CD}=$ Cafedirect, $\mathrm{S}=$ Sainsbury, $\mathrm{T}=$ Tesco.

Lavazza has strongly pushed toward sustainability ( $40 \%$ in both EP and SP). Cafèdirect in UK has joined Altromercato to highlight a common strategy of these two fully Fair-Trade producers. The changes have been represented in the Table 6, and in Figure 3.

Table 6 . The change in the 5 years

\begin{tabular}{|c|c|c|c|c|c|c|c|}
\hline \multirow[b]{2}{*}{ Company } & \multirow[b]{2}{*}{ Abbreviation } & \multicolumn{2}{|l|}{2014} & \multicolumn{2}{|l|}{2018} & \multicolumn{2}{|l|}{ GAP } \\
\hline & & ENV SRD & Social SRD & ENV SRD & Social SRD & $\begin{array}{l}\text { ENV } \\
\text { SRD }\end{array}$ & $\begin{array}{l}\text { Social } \\
\text { SRD }\end{array}$ \\
\hline Alce Nero & $\mathrm{AN}$ & $100 \%$ & $100 \%$ & $100 \%$ & $100 \%$ & $0 \%$ & $0 \%$ \\
\hline Altromercato & $\mathrm{AM}$ & $58 \%$ & $100 \%$ & $58 \%$ & $100 \%$ & $0 \%$ & $0 \%$ \\
\hline Cafè do Brazil & $\mathrm{K}$ & $0 \%$ & $0 \%$ & $8 \%$ & $8 \%$ & $8 \%$ & $8 \%$ \\
\hline Carrefur & $\mathrm{CF}$ & $0 \%$ & $0 \%$ & $13 \%$ & $13 \%$ & $13 \%$ & $13 \%$ \\
\hline CONAD & $\mathrm{CON}$ & $25 \%$ & $25 \%$ & $13 \%$ & $13 \%$ & $-13 \%$ & $-13 \%$ \\
\hline Coop & $\mathrm{CP}$ & $40 \%$ & $40 \%$ & $25 \%$ & $25 \%$ & $-15 \%$ & $-15 \%$ \\
\hline Ecor & $\mathrm{EC}$ & $100 \%$ & $100 \%$ & $100 \%$ & $100 \%$ & $0 \%$ & $0 \%$ \\
\hline Illy Caffè & IL & $0 \%$ & $0 \%$ & $0 \%$ & $0 \%$ & $0 \%$ & $0 \%$ \\
\hline Lavazza & LV & $0 \%$ & $0 \%$ & $42 \%$ & $42 \%$ & $42 \%$ & $42 \%$ \\
\hline Passalacqua & PL & $0 \%$ & $0 \%$ & $0 \%$ & $0 \%$ & $0 \%$ & $0 \%$ \\
\hline Cafedirect & $\mathrm{CD}$ & $0 \%$ & $100 \%$ & $43 \%$ & $100 \%$ & $43 \%$ & $0 \%$ \\
\hline Sainsbury & $\mathrm{S}$ & $5 \%$ & $100 \%$ & $6 \%$ & $100 \%$ & $1 \%$ & $0 \%$ \\
\hline Tesco & $\mathrm{T}$ & $44 \%$ & $56 \%$ & $46 \%$ & $54 \%$ & $2 \%$ & $-2 \%$ \\
\hline
\end{tabular}




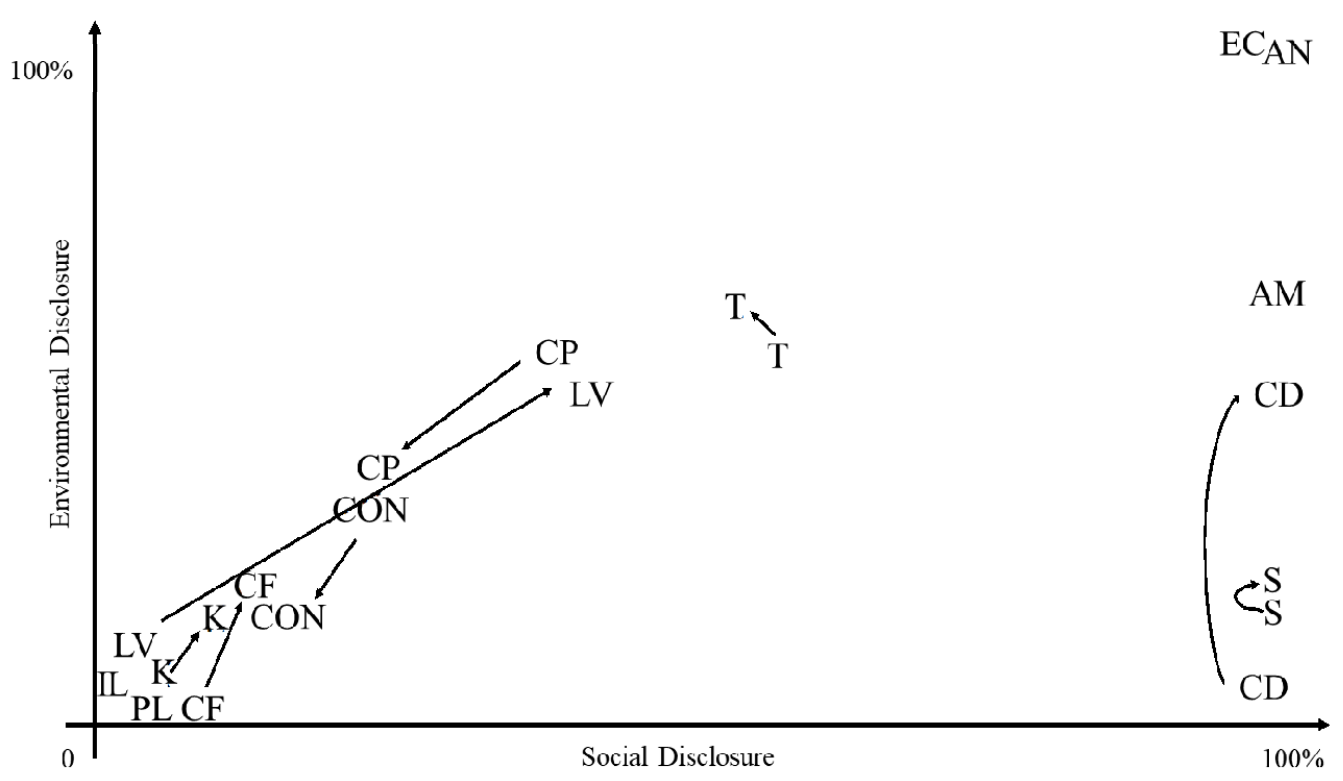

Figure 3. SRD by coffee brands in the 2018

Note. $\mathrm{AN}=\mathrm{Alce}$ Nero, $\mathrm{AM}=$ Altromercato, $\mathrm{K}=\mathrm{Cafè}$ do Brazil, $\mathrm{CF}=$ Carrefur, $\mathrm{CON}=\mathrm{CONAD}, \mathrm{CP}=\mathrm{Coop}, \mathrm{EC}=\mathrm{E}$ cor, $\mathrm{IL}=\mathrm{Illy} \mathrm{Caffè,} \mathrm{LV}=\mathrm{Lavazza}$, $\mathrm{PL}=$ Passalacqua, $\mathrm{CD}=$ Cafedirect, $\mathrm{S}=$ Sainsbury, $\mathrm{T}=$ Tesco.

\section{Conclusions and Future Research Directions}

Our preliminary findings show that companies in the Coffee Industry are reacting to the consumers' requests of a behavior not only by the company but by their whole supply chain.

In particular, we have found that in the 2014 there was a clear division between the two markets as in the UK there was a stronger adoption of the Fair-Trade label that. This label is mostly focused on the social aspects of sustainable development even if it asks companies to act for limiting the damages to the environment.

In Italy, we have found a stronger pressure towards the environmental side of CSR even if the players adopting the Ecolabel have even adopted the Fair-Trade label in order to attest their behavior in the social dimension of sustainability.

During the last years, the pressure towards sustainability have driven some of the traditional companies to create specific product lines to attract the more sensitive part of the market, with the exceptional growth of Lavazza that has decided to create a specific line so it now certifies the $40 \%$ of their product lines (not sales). Using this strategy, these players have been able to play in several different segments, as shown by the increased number of product lines (from 54 to 76 in Italy).

The data show that the difference between the two market has slowly been reducing as the companies in both markets are starting to leverage social responsibility disclosure in both dimensions.

Our paper gives the first evidences on how the consumers' perception of organic and Fair-Trade is changing over the years. In effect, the results highlight new several directions that suggest further analysis. Both the topics are converging toward a similar role in the consumer point of view.

A first limitation of the study is that we did not consider the impact on the consumer perception of the new coffee caps (Nespresso, Dolce Gusto, and so on). The caps are more certified than ground coffee, probably to justify the worse impact on the environment linked to the plastic pods. As these products are usually sold for higher prices, they create the resources to buy more certification and to source in a more responsible way. This is an intresting factor that could be deepen in a further analysis.

On the other side, our study does not give evidence on the differences linked to each specific label and how they really impact on the consumer's perception. So, a suggestion for a further analysis could be considering factor in the real market effects linked to new more sustainable product lines gathering data on the consumer perception referring these labels, in order to understand if consumers knows the differences among them or, at least, if they 
are able to discern among them.

\section{References}

Ampuero, O., \& Vila, N. (2006). Consumer perceptions of product packaging. Journal of Consumer Marketing, 23(2), 100-112. https://doi.org/10.1108/07363760610655032

Arnot, C., Boxall, P. C., \& Cash, S. B. (2006). Do ethical consumers care about price? A revealed preference analysis of fair-trade coffee purchases. Canadian Journal of Agricultural Economics/Revue canadienne d'agroeconomie, 54(4), 555-565. https://doi.org/10.1111/j.1744-7976.2006.00066.x

Auger, P., Burke, P., Devinney, T. M., \& Louviere, J. J. (2003). What will consumers pay for social product features? Journal of Business Ethics, 42(3), 281-304. https://doi.org/10.1023/A:1022212816261

Auger, P., Devinney, T. M., Louviere, J. J., \& Burke, P. F. (2008). Do social product features have value to consumers? International Journal of Research in Marketing, 25(3), 183-191. https://doi.org/10.1016/j.ijresmar.2008.03.005.

Azad, N., \& Hamdavipour, L. (2012). A study on effects of packaging characteristics on consumer's purchasing confidence. Management Science Letters, 2(1), 397-402. https://doi.org/10.5267/j.msl.2011.07.004

Berthelot, S., Cormier, D., \& Magnan, M. (2003). Environmental disclosure research: review and synthesis. Journal of Accounting Literature, 22, 1-44. Retrieved from https://www.researchgate.net/profile/Sylvie_Berthelot/publication/285059735_Environmental_disclosure_r esearch_Review_and_synthesis/links/59f37e36aca272607e29144b/Environmental-disclosure-research-Revi ew-and-synthesis.pdf

Boardman, J., \& Sauser, B. (2008). Systems thinking: Coping with 21st century problems. USA: CRC Press. https://doi.org/10.1201/9781420054927

Bone, P. F., \& Corey, R. J. (2000). Packaging ethics: Perceptual differences among packaging professionals, brand managers and ethically-interested consumers. Journal of Business Ethics, 24(3), 199-213. https://doi.org/10.1023/A:1006257523743

Branco, M. C., \& Rodrigues, L. L. (2008). Factors influencing social responsibility disclosure by Portuguese companies. Journal of Business Ethics, 83(4), 685-701. https://doi.org/10.1007/s10551-007-9658-z

Brown, T. J., \& Dacin, P. A. (1997). The company and the product: Corporate associations and consumer product responses. Journal of Marketing, 61(1), 68-84. https://doi.org/10.1177/002224299706100106

Carroll, A. B., \& Shabana, K. M. (2010). The business case for corporate social responsibility: a review of concepts, research and practice. International Journal of Management Reviews, 12(1), 85-105. https://doi.org/10.1111/j.1468-2370.2009.00275.x

Catturani, I., Nocella, G., Romano, D., \& Stefani, G. (2008). Segmenting the Italian coffee market: marketing opportunities for economic agents working along the international coffee chain (No. 725-2016-49556). Paper presented at the 12th Congress of the European Association of Agricultural Economists, Ghent, Belgium. Retrieved from https://ideas.repec.org/p/ags/eaae08/44146.html

Chauvey, J. N., Giordano-Spring, S., Cho, C. H., \& Patten, D. M. (2015). The normativity and legitimacy of CSR disclosure: Evidence from France. Journal of Business Ethics, 130(4), 789-803. https://doi.org/10.1007/s10551-014-2114-y

Codron, J. M., Siriex, L., \& Reardon, T. (2006). Social and environmental attributes of food products in an emerging mass market: Challenges of signaling and consumer perception, with European illustrations. Agriculture and Human Values, 23(3), 283-297. https://doi.org/10.1007/s10460-006-9000-x

Dawkins, J., \& Lewis, S. (2003). CSR in Stakeholder Expectations: And Their Implication for Company Strategy. Journal of Business Ethics, 44(2-3), 185-193. https://doi.org/10.1023/A:1023399732720

De Pelsmacker, P., Driesen, L., \& Rayp, G. (2005). Do consumers care about ethics? Willingness to pay for fair - trade coffee. Journal of Consumer Affairs, 39(2), 363-385. https://doi.org/10.1111/j.1745-6606.2005.00019.x

De Pelsmacker, P., \& Janssens, W. (2007). A model for fair trade buying behaviour: The role of perceived quantity and quality of information and of product-specific attitudes. Journal of Business Ethics, 75(4), 361-380. https://doi.org/10.1007/s10551-006-9259-2

Deegan, C. (2002). The Legitimising Effect of Social and Environmental Disclosures-A Theoretical Foundation. 
Accounting, Auditing \& Accountability Journal, 15(3), 282-311. https://doi.org/10.1108/09513570210435852

Donaldson, T., \& Dunfee, T. W. (2002). Ties that bind in business ethics: Social contracts and why they matter. Journal of Banking \& Finance, 26(9), 1853-1865. https://doi.org/10.1016/S0378-4266(02)00195-4

Dubbink, W., Graafland, J., \& Van Liedekerke, L. (2008). CSR, transparency and the role of intermediate organisations. Journal of Business Ethics, 82(2), 391-406. https://doi.org/10.1007/s10551-008-9893-y

Ekeh, P. P. (1974). Social Exchange Theory: The Two Traditions. London: Heinemann. Retrieved from https://www.jstor.org/stable/pdf/42859591.pdf?ab_segments=0\%252Ftbsub1\%252Frelevance_config_with_ defaults\&refreqid=excelsior\%3A67fa732fa718e4c0966e44501f5278a1

Elkington, J. (1994). Towards the sustainable corporation: Win-win-win business strategies for sustainable development. California Management Review, 36(2), 90-100. https://doi.org/10.2307/41165746

Folkes, V. S., \& Kamins, M. A. (1999). Effects of information about firms' ethical and unethical actions on $\begin{array}{lllll}\text { consumers' attitudes. Journal of Consumer Psychology, 8(3), 259. } & \text { 243 }\end{array}$ https://doi.org/10.1207/s15327663jcp0803_03

Font, X., \& Harris, C. (2004). Rethinking standards from green to sustainable. Annals of Tourism Research, 31(4), 986-1007. https://doi.org/10.1016/j.annals.2004.04.001

Freeman, R. E. (1984). Strategic management: A stakeholder approach. Boston: Pitman.

Freeman, R. E. (2010). Strategic management: A stakeholder approach. Cambridge: Cambridge University Press. https://doi.org/10.1017/CBO9781139192675

Frooman, J. (1999). Stakeholder influence strategies. Academy of Management Review, 24, 191-205. https://doi.org/10.2307/259074

Galarraga Gallastegui, I. (2002). The use of eco - labels: a review of the literature. European Environment, 12(6), 316-331. https://doi.org/10.1002/eet.304

Godfrey, P. C. (2005). The relationship between corporate philanthropy and shareholder wealth: A risk management perspective. Academy of Management Review, 30(4), 777-798. https://doi.org/10.5465/amr.2005.18378878

Hanss, D., \& Böhm, G. (2012). Sustainability seen from the perspective of consumers. International Journal of Consumer Studies, 36(6), 678-687. https://doi.org/10.1111/j.1470-6431.2011.01045.x

Harrison, J. S., Bosse, D. A., \& Phillips, R. A. (2010). Managing for stakeholders, stakeholder utility functions, and competitive advantage. Strategic Management Journal, 31(1), 58-74. https://doi.org/10.1002/smj.801

Harrison, J. S., \& Wicks, A. C. (2013). Stakeholder theory, value, and firm performance. Business Ethics Quarterly, 23(1), 97-124. https://doi.org/10.5840/beq20132314

Hooghiemstra, R. (2000). Corporate Communication and Impression Management: New Perspectives Why Companies Engage in Corporate Social Reporting. Journal of Business Ethics, 27(1/2), 55-68. https://doi.org/10.1007/978-94-011-4311-0_7

Ingram, R. W. (1978). An investigation of the information content of (certain) social responsibility disclosures. Journal of Accounting Research, 270-285. https://doi.org/10.2307/2490567

Jenkins, H., \& Yakovleva, N. (2006). Corporate social responsibility in the mining industry: Exploring trends in social and environmental disclosure. Journal of Cleaner Production, 14(3), 271-284. https://doi.org/10.1016/j.jclepro.2004.10.004

Kolk, A. (2003). Trends in Sustainability Reporting by the Fortune Global 250. Business Strategy and the Environment, 12(5), 279-291. https://doi.org/10.1002/bse.370

Lamberti, L., \& Lettieri, E. (2009). CSR practices and corporate strategy: Evidence from a longitudinal case study. Journal of Business Ethics, 87(2), 153-168. https://doi.org/10.1007/s10551-008-9876-z

Line, M., Hawley, H., \& Krut, R. (2002). The development of global environmental and social reporting. Corporate Environmental Strategy, 9(1), 69-78. https://doi.org/10.1016/S1066-7938(01)00159-2

Maak, T. (2007). Responsible leadership, stakeholder engagement, and the emergence of social capital. Journal of Business Ethics, 74(4), 329-343. https://doi.org/10.1007/s10551-007-9510-5

Mackey, A., Mackey, T. B., \& Barney, J. B. (2007). Corporate social responsibility and firm performance: 
Investor preferences and corporate strategies. Academy of Management Review, 32(3), 817-835. https://doi.org/10.5465/amr.2007.25275676

Markley, M. J., \& Davis, L. (2007). Exploring future competitive advantage through sustainable supply chains. International Journal of Physical Distribution \& Logistics Management, 37(9), 763-774. https://doi.org/10.1108/09600030710840859

Matos, S., \& Hall, J. (2007). Integrating sustainable development in the supply chain: The case of life cycle assessment in oil and gas and agricultural biotechnology. Journal of Operations Management, 25(6), 1083-1102. https://doi.org/10.1016/j.jom.2007.01.013

McDaniel, C., \& Baker, R. C. (1977). Convenience food packaging and the perception of product quality. Journal of Marketing, October, 57-58. Retrieved from https://search.proquest.com/openview/e4dffb21e0fc4b2ac5bdf224bd5cf46c/1?pq-origsite=gscholar\&cbl=18 16480

Mohr, L. A., Webb, D. J., \& Harris, K. E. (2001). Do consumers expect companies to be socially responsible? The impact of corporate social responsibility on buying behavior. Journal of Consumer Affairs, 35(1), 45-72. https://doi.org/10.1111/j.1745-6606.2001.tb00102.x

Neu, D., Warsame, H., \& Pedwell, K. (1998). Managing public impressions: environmental disclosures in annual reports. Accounting, Organizations and Society, 23(3), 265-282. https://doi.org/10.1016/S0361-3682(97)00008-1

Nilsson, H., Tunçer, B., \& Thidell, Å. (2004). The use of eco-labeling like initiatives on food products to promote quality assurance-Is there enough credibility? Journal of Cleaner production, 12(5), 517-526. https://doi.org/10.1016/S0959-6526(03)00114-8

Papaluca, O., \& Tani, M. (2016). An integrated approach of Innovations for sustainability: first evidences from some enterprises in Campania. In R. Mercurio (Ed.), Organizational Networks for Innovations (pp. 251-265). Milano: Egea.

Passet, R. (1996). L'économique et le vivant (2e éd.). Paris: Economica. https://doi.org/10.3917/econo.passe.1996.01

Pearce, R. (1999). Social responsibility in the marketplace: asymmetric information in food labelling. Business Ethics: A European Review, 8(1), 26-36. https://doi.org/10.1111/1467-8608.00122

Perna, T. (1998). Fair Trade: la sfida etica al mercato mondiale. Torino: Bollati Boringhieri.

Pfeffer, C., \& Salancik G. (1978). The External Control of Organization. New York: Harper \& Row.

Porter, M. E., \& Kramer, M. R. (2006). The link between competitive advantage and corporate social responsibility. Harvard Business Review, 84(12), 78-92. Retrieved from https://luciekuldova.webnode.cz/_files/2000001957147e72439/The\%20Link\%20Between\%20Competitive \%20Advantage \%20and\%20Corporate\%20Social\%20Responsibility.pdf

Prendergast, P. G., \& Pitt, L. (1996). Packaging, marketing, logistics and the environment: are there trade-offs? International Journal of Physical Distribution \& Logistics Management, 26(6), 60-72. https://doi.org/10.1108/09600039610125206

Rettie, R., \& Brewer, C. (2000). The verbal and visual components of package design. Journal of Product \& Brand Management, 9(1), 56-70. https://doi.org/10.1108/10610420010316339

Rokka, J., \& Uusitalo, L. (2008). Preference for green packaging in consumer product choices-Do consumers care? International Journal of Consumer Studies, 32(5), 516-525. https://doi.org/10.1111/j.1470-6431.2008.00710.x

Sciarelli, M. (2012). Corporate social performance: il valore allargato nella prospettiva degli stakeholder. Padova: Cedam

Sciarelli, M., Tani, M., Landi, G., \& Papaluca, O. (2019). The Impact of Social Responsibility Disclosure on Corporate Financial Health: Evidences from Some Italian Public Companies. International Business Research, 12(3), 109-122. https://doi.org/10.5539/ibr.v12n3p109

Silayoi, P., \& Speece, M. (2007). The importance of packaging attributes: a conjoint analysis approach. European journal of marketing, 41(11/12), 1495-1517. https://doi.org/10.1108/03090560710821279

Teisl, M. F., Rubin, J., \& Noblet, C. L. (2008). Non-dirty dancing? Interactions between eco-labels and 
consumers. Journal of Economic Psychology, 29(2), 140-159. https://doi.org/10.1016/j.joep.2007.04.002

Thøgersen, J. (2000). Psychological determinants of paying attention to eco-labels in purchase decisions: Model development and multinational validation. Journal of Consumer Policy, 23(3), 285-313. https://doi.org/10.1023/A:1007122319675

Underwood, R. L. (2003). The communicative power of product packaging: creating brand identity via lived and mediated experience. Journal of Marketing Theory and Practice, Winter, 62-76. https://doi.org/10.1080/10696679.2003.11501933

Van Amstel, M., Driessen, P., \& Glasbergen, P. (2008). Eco-labeling and information asymmetry: A comparison of five eco-labels in the Netherlands. Journal of Cleaner Production, 16(3), 263-276. https://doi.org/10.1016/j.jclepro.2006.07.039

Wansink, B., Sonka, S. T., \& Hasler, C. M. (2004). Front-label health claims: when less is more. Food Policy, 29(6), 659-667. https://doi.org/10.1016/j.foodpol.2004.10.004

Yin, R. K. (2003). Case Study Research: Design and Methods. Beverly Hills: Sage.

Zimmerman, M. A., \& Zeitz, G. J. (2002). Beyond survival: Achieving new venture growth by building legitimacy. Academy of Management Review, 27(3), 414-431. https://doi.org/10.5465/amr.2002.7389921

\section{Notes}

Note 1. The acronym FLO is used to mean Fair-Ttrade International, otherwise known as in many countries Fair-Trade Labelling Organizations International.

Note 2. Rainforest Alliance is an international non-profit organization working to create a better future for people and nature. Its seal means an environmental certification on sustainable forestry and agriculture. The Rainorest Alliance certification gives information to consumers over about business practices, based on certain standards.

Note 3. UTZ - formerly called UTZ Certified - is a program and a label for sustainable farming of coffee, tea, cocoa and hazelnuts. From 2018, the program is part of the Rainforest Alliance.

\section{Copyrights}

Copyright for this article is retained by the author, with first publication rights granted to the journal.

This is an open-access article distributed under the terms and conditions of the Creative Commons Attribution license (http://creativecommons.org/licenses/by/4.0/). 